\title{
Experimental Study on the Effect of Cross Bracing on the Behaviour of Composite Bridges
}

\author{
Badria A. M Fageer ${ }^{1, *}$, Abdalla Ahmed ${ }^{2}$ and Osama Daoud ${ }^{3}$ \\ 1 Department of Civil Engineering, Red Sea University, Khartoum, Sudan \\ 2 Department of Civil Engineering, University of Khartoum, Khartoum, Sudan \\ 3 Building and Road Research Institute, University of Khartoum, Sudan \\ * Corresponding author: Badria Fageer (e-mail: b_fageery@yahoo.com).
}

Article history: Received 10 March 2020, Received in revised form 4 November 2020, Accepted 11 November 2020

\begin{abstract}
In this paper the results of an experimental program were presented to show the effect of cross bracing on the behavior of composite bridges. Two types of models were prepared in the laboratories of the American University in Cairo Egypt. These models were chosen to be one tenth scale of the model of the Federal Highway Administration (FHWA). Deflections and strains were measured for each model according to the set of bracing and comparisons were made to show the effect of bracing.
\end{abstract}

Keywords: Composite bridge, cross frame, curved bridges, experimental program.

\section{INTRODUCTION}

Presently, many cities face problems of space limitation for the transportation systems. One probable solution is to construct bridges with special configurations. Horizontally curved composite bridges are among the most economical options for satisfying these demands. To develop and improve a rational set of design guidelines, the Federal Highway Administration (FHWA) initiated the curved steel bridge research project in 1992, and constructed a full-scale model of curved steel girder bridge at its TurnerFairbank Structures Laboratory. This full- scale model made it possible to conduct numerous tests and collect a significant amount of data relating to the static behavior of curved girder bridge, [1].

The most commonly used member for horizontally curved bridges is steel I-girders, which provide minimal torsional resistance and can only be considered stable if they are connected with other girders using cross-frames or diaphragms, [2].
The behavior of bridges having horizontally curved geometry complicates their design and erection. In these systems, because of the geometry of the structure, gravity loading not only causes a vertical deflection in the girder, but also twisting of the girder cross section. In this case, the cross-frames, in addition to restraining the lateral-torsional deformations, also play an important role in the distribution and transfer of load between girders and are recognized as primary members (primary members should be designed for strength and fatigue), [2], [3] and [4].

In the curved I-girder bridges the internal torsion in curved bridges exists independently of the interconnection of the girders by the cross-frames. If the curved I-girders are not connected to the overall bridge structural system by the cross-frames, they tend to exhibit large torsional deflections. The predominant resistance to the above internal torsion in horizontally-curved I-girder bridges is developed by interconnecting the girders across the entire bridge width by the cross frames [5]. 
Modern highway construction often requires bridges with horizontally curved alignments. According to 1991 survey [6]. Curved bridges represent 20 to 25 percent of the market for new steel bridge construction each year and this trend is likely to increase in the future. Construction of horizontally curved steel bridges is also generally more complex than construction of straight -girder bridges of similar span. Curved -girder bridges, once completed have generally performed as intended, [6].

In straight bridges, cross-frames and diaphragms are considered as secondary load carrying components, while in curved bridges, they acting as primary load carrying components, [7]. Another important structural role of cross-frames in curved bridges is the reduction of warping stress and bending stress, [8]. Furthermore, the increase on the number of cross-frames can improve the overall stiffness of the girder system. However, designers must also take into consideration the increase in its economic cost, [9].

\section{DESIGN, FABRICATION, AND TESTING OF MODELS}

\subsection{I-girder Dimensions and Details:}

The models used in this study have been scaled as one tenth of the FHWA full scale model which was used for long-term tests, Fig. 1. The composite section, then designed according to the AASHTTO 2003 guide specification, [10]. The design is based on the assumption that the neutral axis of the composite section lies in the top flange. The models are to be single simply supported span. The straight model is $2.6 \mathrm{~m}$ length while the curved model varies from $2.87 \mathrm{~m}$ for the outer girder to 2.33 for the inner girder. The cross frame was chosen to be X-type configurations constructed of $40 * 40 * 3 \mathrm{~mm}$ angle sections of steel grade 37, [11]. Steel studs were used as shear connectors with $13 \mathrm{~mm}$ diameter of steel grade 37 , Fig. 2 to Fig. 4.

The steel I-girders are chosen from IPE 160 sections, (see Table I). They are placed at $0.6 \mathrm{~m}$ spacing. The curved girders for the curved model were curved by the roller-machine to radii $R$ $6.36 \mathrm{~m}$ for the outer girder, $5.673 \mathrm{~m}$ for the middle girder and $4.56 \mathrm{~m}$ for the inner girder. The shear connectors were welded to the top flanges of the I-girders for the two types of models.

The models were set according to the specified spacing $(0.6 \mathrm{~m})$ and the cross frames were installed at the required positions according to predetermined spacing. A $100 \mathrm{~mm}$ thick concrete was casted in situ to complete the composite section. The concrete was made of strength $\left(f_{\mathrm{cu}}{ }^{\prime}\right)$ of $38 \mathrm{~N} / \mathrm{mm}^{2}$. The concrete modulus of elasticity used in the design calculation was taken as 25 $\mathrm{N} / \mathrm{mm}^{2}$. Two layers of steel reinforcement were used from bars of $8 \mathrm{~mm}$ and $6 \mathrm{~mm}$ diameters, Fig. 5.

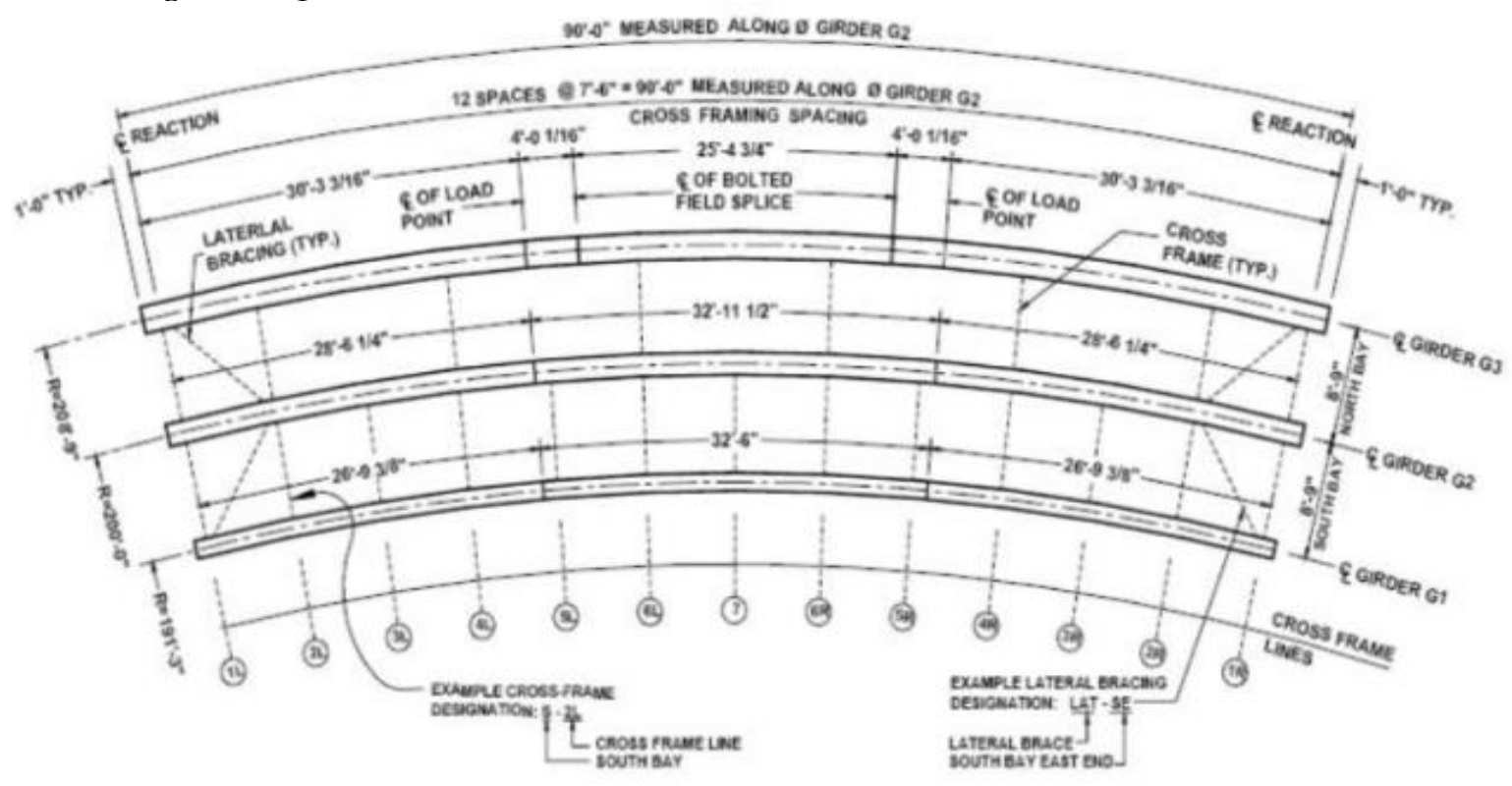

Fig. 1: FHWA curved bridge testing model 
TABLE I: PROPERTIES OF STEEL I-GIRDER

\begin{tabular}{cc}
\hline \hline Section type & IPE 160 \\
\hline Depth mm & 160 \\
Width mm & 82 \\
$\mathrm{~T}_{\mathrm{f}}$ & 7.4 \\
$\mathrm{t}_{\text {web }}$ & 5 \\
Area cm & 20.136 \\
Weight $\mathrm{kg} / \mathrm{m}$ & 15.3 \\
\hline \hline
\end{tabular}

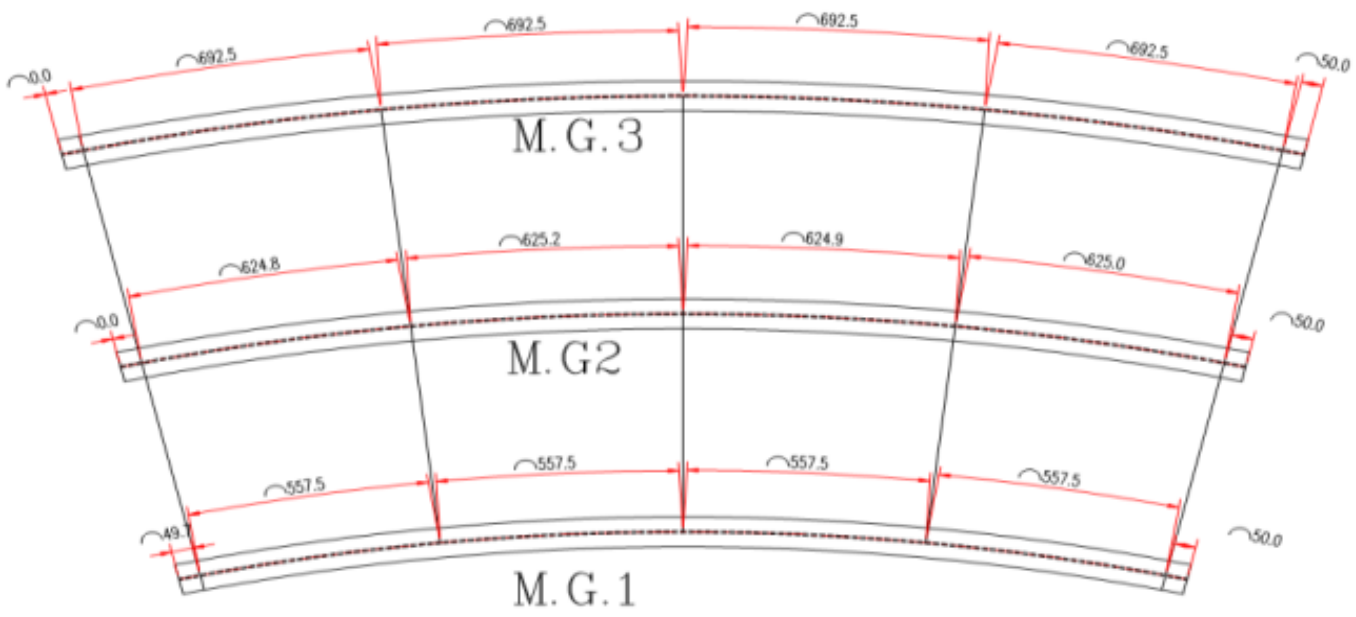

Fig. 2: Steel frame plan

IPE 160

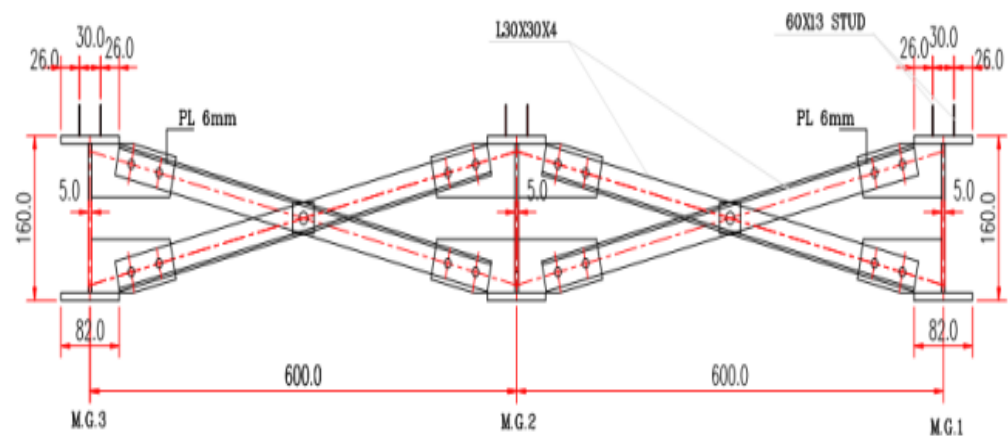

Fig. 3: Steel cross section

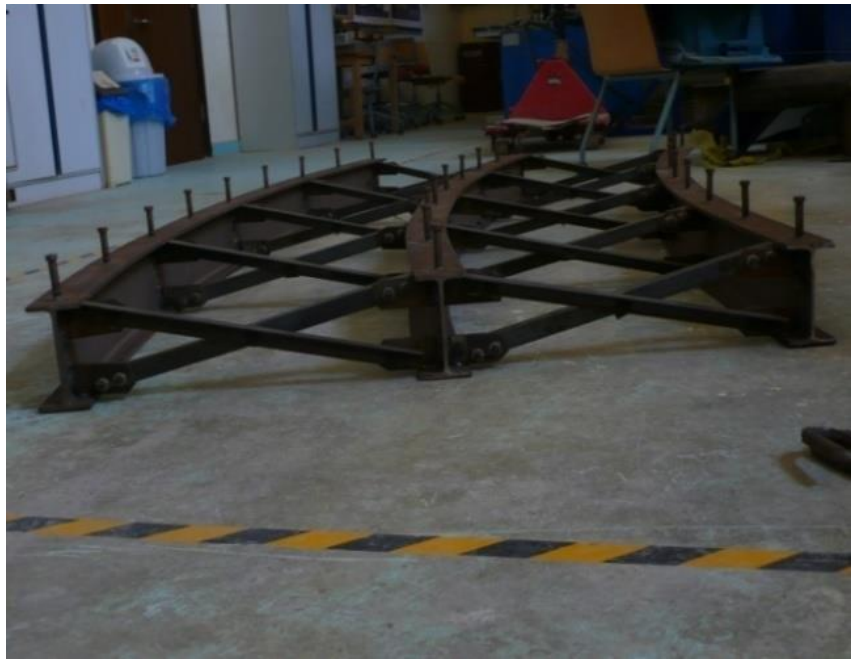

Fig. 4: Steel frame of curved model

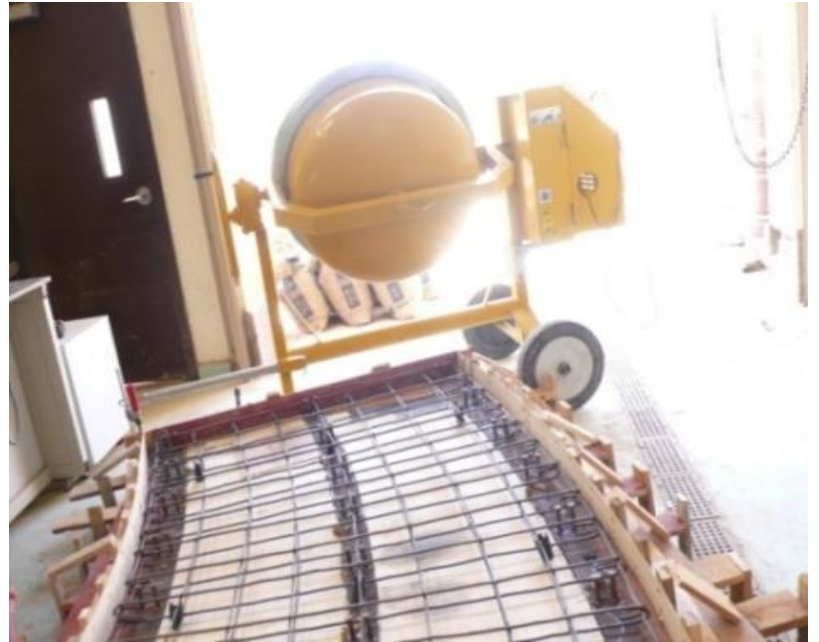

Fig. 5: Ditributions of reinforcement and form work 


\section{TEST SETUP AND INSTRUMENTATION}

The models were tested by using a test frame and 200 Ton Static actuator with two hydraulic power systems, Fig. 8. Each model was simply supported on two braced rigid beams by a system of steel plates and rollers. The load was applied through a set of rigid beams, at six points (two on each beam). The loading system is applied so that $50 \%$ of the total load on the middle girder and $25 \%$ on the each of the other girders, Fig. 6, and Fig. 7. In order to measure the deflection, Five linear variable differential transducer (LVDT) sensors were used, three of them to measure maximum deflection of each girder and the other two at the ends of the middle girder, Fig. 9. Also strain gauges were fixed to measure maximum strains at top and bottom flange and web of each girder.

Each model was subjected to an incremental load up to 20 Ton maximum load and resulting deflections and strains were recorded for each model and each set of cross- bracings.

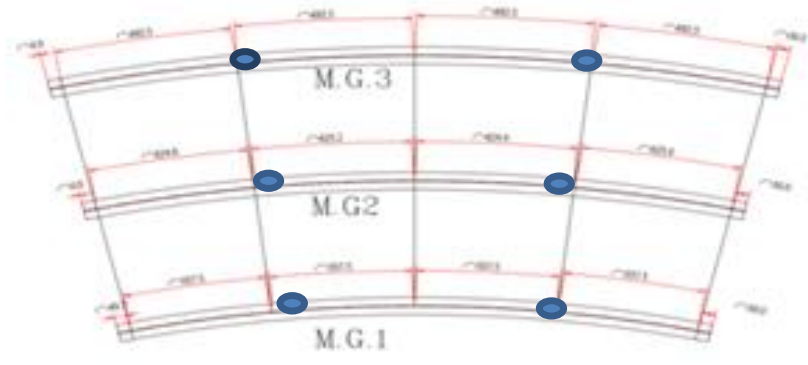

Fig. 6. Plan of model load points

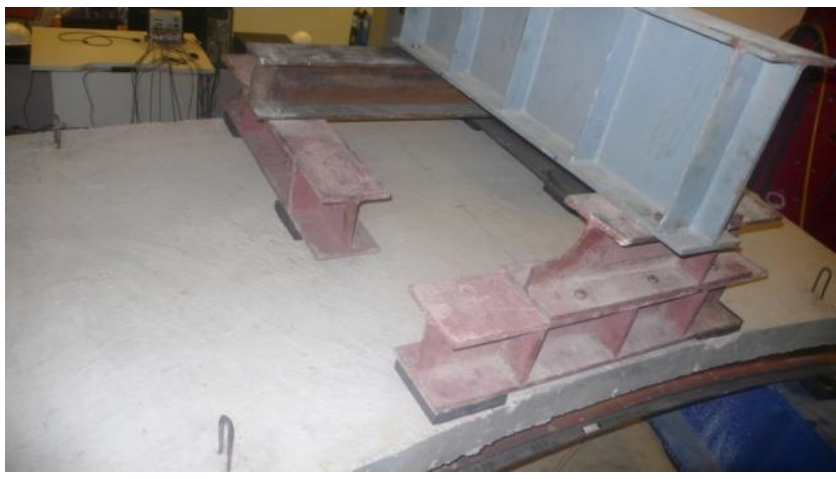

Fig. 7. Curved model six point for distribution

\subsection{Parametric Study Testing Procedure:}

To study the influence of the cross frame spacing variation, on the strain and deflection of both curved and straight models under linear static load, a parametric study was conducted.

For each model a 20-ton monotonic static load was applied in three phases;

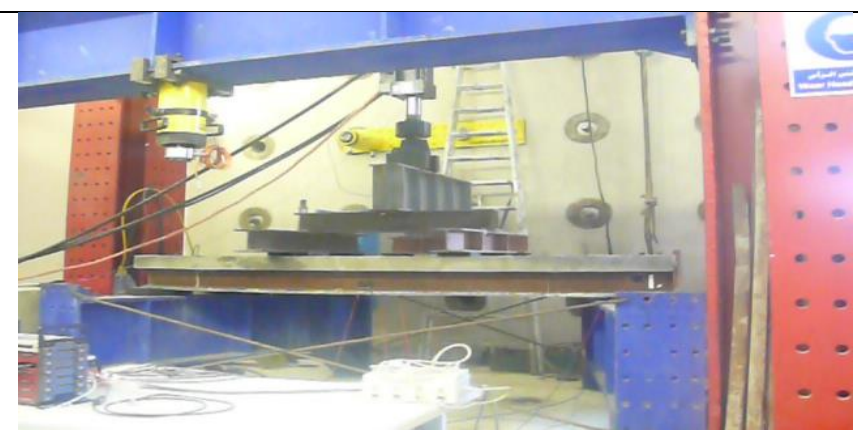

Fig. 8. 500 Ton steel frame and two braced rigid beam

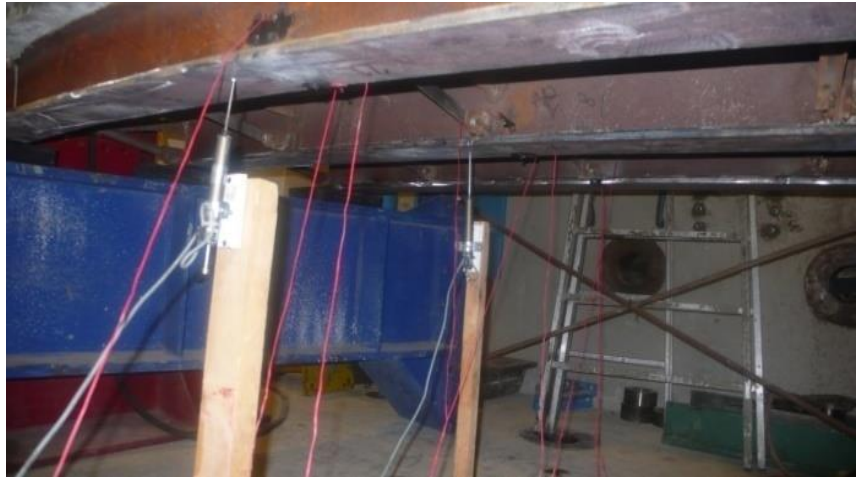

Fig. 9. Curved model instrumentations

- Firstly, for the model with only two cross frames installed at each end,

- In the second phase beside two cross frames at each end, one additional intermediate cross frame was added at the center of the model,

- And finally in the third phase beside two cross frames at each end, three additional intermediate cross frame was added at the center of the model; with spacing at $650 \mathrm{~mm}$ intervals across the center girder.

\section{RESULTS ANALYSIS AND DISCUSSION}

\subsection{Deflections for Each Girder:}

The load deflection curve for each girder for each model with a set of cross bracing were given in Fig. 10 to Fig. 12.

The maximum deflections measured for each girder in each model according to the set of cross bracings are given in tables (II to IV).

TABLE II: MAXIMUM DEFLECTIONS AT CENTER LINE OF INTERIOR GIRDER OF STRAIGHT AND CURVED MODELS

\begin{tabular}{|c|c|c|c|c|}
\hline \multirow[b]{2}{*}{$\begin{array}{l}\text { Cross } \\
\text { Frames }\end{array}$} & \multicolumn{2}{|c|}{ Curved model } & \multicolumn{2}{|c|}{ Straight model } \\
\hline & $\begin{array}{c}\text { Maximum } \\
\text { Deflection } \\
\quad(\mathrm{mm})\end{array}$ & $\begin{array}{l}\text { Percentage } \\
\text { difference }\end{array}$ & $\begin{array}{c}\text { Maximum } \\
\text { Deflection } \\
\quad(\mathrm{mm})\end{array}$ & $\begin{array}{l}\text { Percentage } \\
\text { difference }\end{array}$ \\
\hline Two & 2.066 & & 2.066 & \\
\hline Three & 2.89 & $28.5 \%$ & 2.066 & $0 \%$ \\
\hline Five & 3.29 & $22.62 \%$ & 1.65 & $20.13 .4 \%$ \\
\hline
\end{tabular}




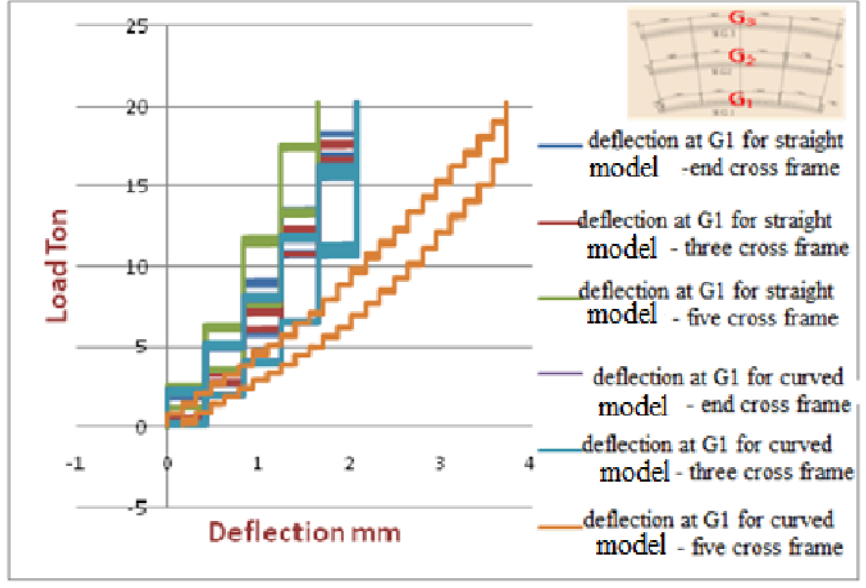

Fig. 10. Deflection at the center line of interior girder of straight and curved models

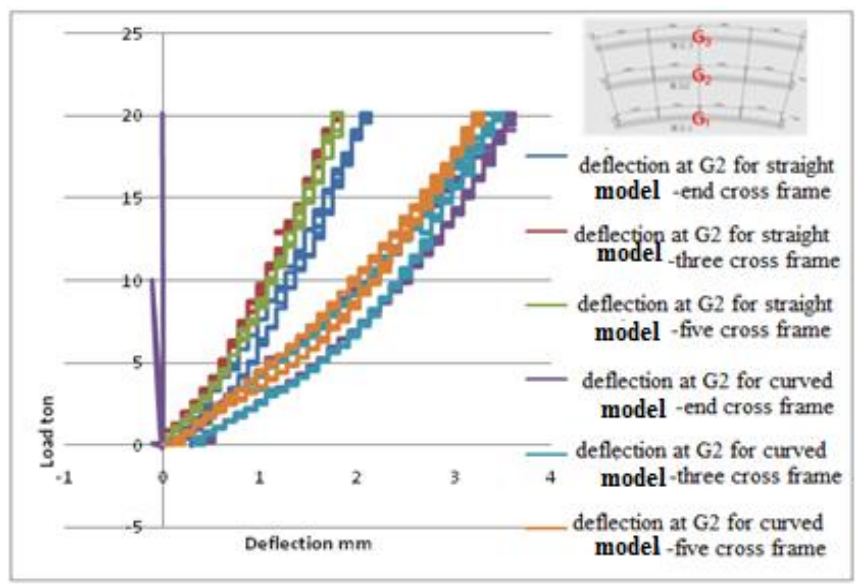

Fig. 11. Deflections at middle girder of straight and curved models

TABLE III: MAXIMUM DEFLECTION AT MIDDLE GIRDER OF STRAIGHT AND CURVED MODELS

\begin{tabular}{ccc|cc}
\hline \hline & \multicolumn{2}{c|}{ Curved model } & \multicolumn{2}{|c}{ Straight model } \\
\cline { 2 - 5 } Cross & Maximum & Percentage \\
Frames & $\begin{array}{c}\text { Maximum } \\
\text { Deflection } \\
\text { difference }\end{array}$ & $\begin{array}{c}\text { Percentage } \\
\text { Deflection } \\
(\mathrm{mm})\end{array}$ & & difference \\
\hline Two & 3.60 & & 2.13 & \\
Three & 3.39 & $5.83 \%$ & 1.84 & $13.62 \%$ \\
Five & 3.2 & $5.6 \%$ & 1.84 & $0 \%$ \\
\hline \hline
\end{tabular}

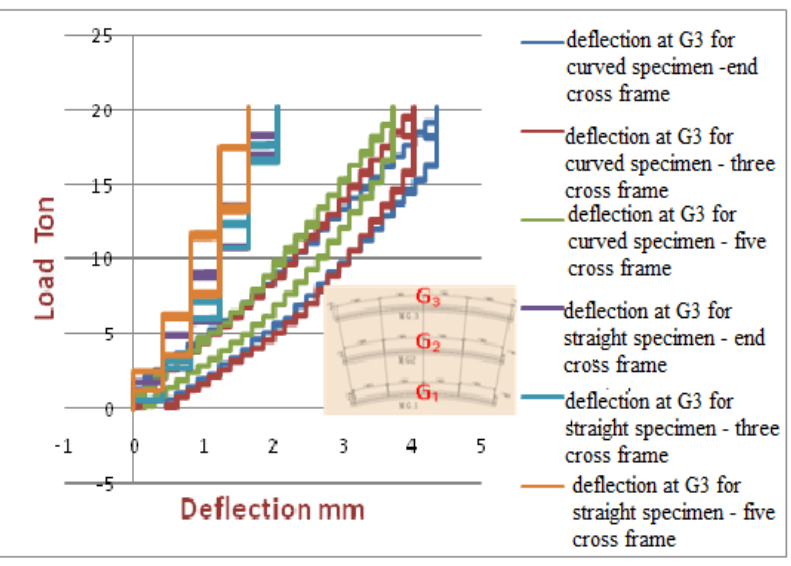

Fig. 12. Deflection at exterior girder of straight and curved models
TABLE IV: MAXIMUM DEFLECTION AT EXTERIOR GIRDER OF CURVED AND STRAIGHT MODELS

\begin{tabular}{|c|c|c|c|c|}
\hline \multirow[b]{2}{*}{$\begin{array}{l}\text { Cross } \\
\text { Frames }\end{array}$} & \multicolumn{2}{|c|}{ Curved model } & \multicolumn{2}{|c|}{ Straight model } \\
\hline & $\begin{array}{l}\text { Maximum } \\
\text { Deflection } \\
(\mathrm{mm})\end{array}$ & $\begin{array}{l}\text { Percentage } \\
\text { difference }\end{array}$ & $\begin{array}{l}\text { Maximum } \\
\text { Deflection } \\
\text { (mm) }\end{array}$ & $\begin{array}{l}\text { Percentage } \\
\text { difference }\end{array}$ \\
\hline Two & 4.34 & & 2.66 & \\
\hline Three & 4.03 & $7.14 \%$ & 2.66 & $0 \%$ \\
\hline Five & 3.72 & $7.7 \%$ & 1.65 & $38 \%$ \\
\hline
\end{tabular}

\subsection{Strains for Each girder:}

The load strain curves measured for each girder for each model with a set of cross bracings were shown in Fig. 13 to Fig. 17.

The maximum strains were also given in table $(\mathrm{V}$ to VIII).

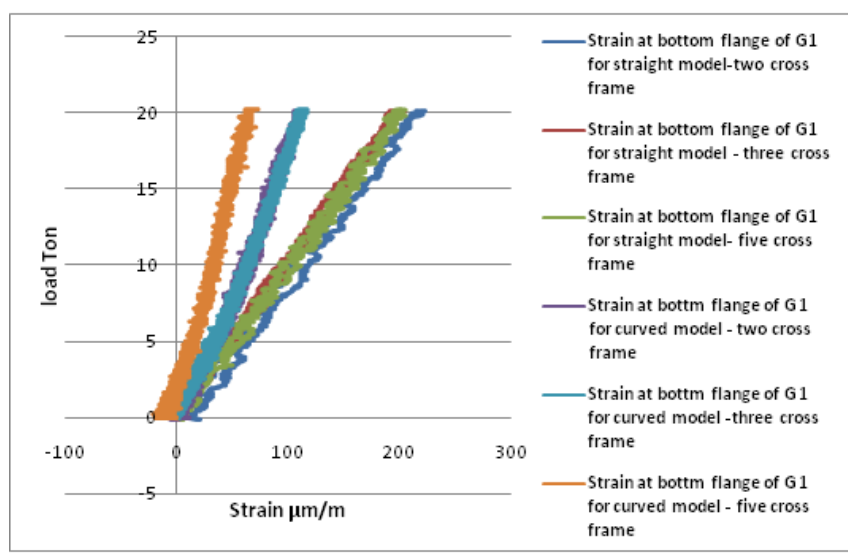

Fig. 13. Strain at the center line of bottom flange of interior girder for straight and curved models

TABLE V: MAXIMUM STRAIN AT BOTTOM FLANGE OF INTERIOR GIRDER (G1) FOR STRAIGHT AND CURVED MODELS

\begin{tabular}{cccc}
\hline \hline Cross frame & $\begin{array}{c}\text { Maximum } \\
\text { strain }\end{array}$ & $\begin{array}{c}\text { Maximum } \\
\text { strain }\end{array}$ & $\begin{array}{c}\text { Maximum } \\
\text { strain }\end{array}$ \\
$\begin{array}{c}\text { Two cross } \\
\text { frames }\end{array}$ & $\begin{array}{c}\mu \mathrm{m} / \mathrm{m} \\
\text { Three cross } \\
\text { frames }\end{array}$ & $\begin{array}{c}\mu \mathrm{m} / \mathrm{m} \\
\text { Five cross } \\
\text { frames }\end{array}$ \\
\hline $\begin{array}{c}\text { Curved } \\
\text { model }\end{array}$ & 212.9 & 116.7 & 68.8 \\
Straight & 222 & 204.7 & 202.8 \\
model & $4.9 \%$ & $43 \%$ & $68.5 .7 \%$ \\
$\begin{array}{c}\text { Percentage } \\
\text { difference }\end{array}$ & & & \\
\hline \hline
\end{tabular}

\subsection{DISCUSSIONS OF RESULTS}

Tables (II to IV) show the behavior of curved and straight models towards cross frame spacing. In the curved model the maximum deflection occurred in exterior girder $(4.34 \mathrm{~mm})$. The deflection value of the curved model was higher 
than that of the straight model by $42.5 \%$, because the configuration of the curved model induces lateral flange moment and torsion moments and the span is longer than others.

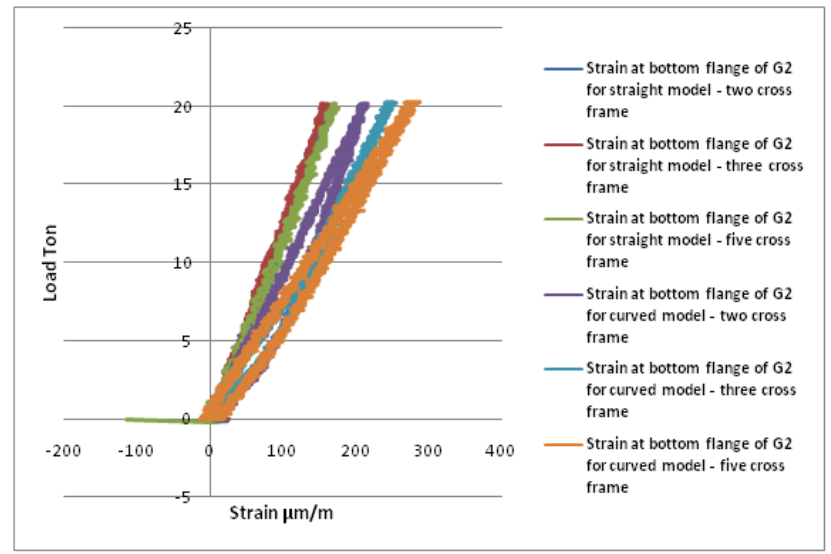

Fig. 14. Strain at bottom flange at the center line of middle girder for straight and curved models.

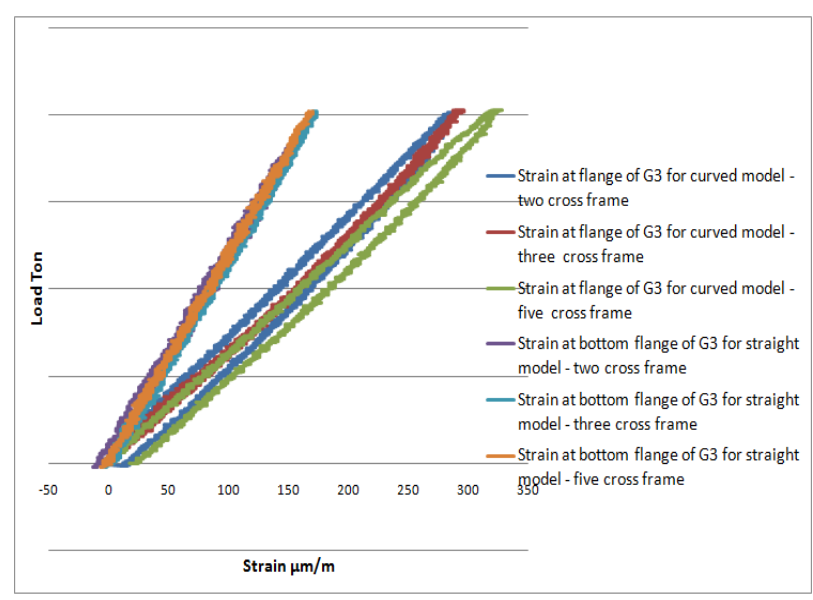

Fig. 15. Strain at bottom flange at the center line of exterior girder for straight and curved models

TABLE VII: MAXIMUM STRAIN AT BOTTOM FLANGE OF EXTERIOR GIRDER FOR STRAIGHT AND CURVED

\begin{tabular}{|c|c|c|c|}
\hline Cross frame & $\begin{array}{l}\text { Maximum } \\
\text { strain } \\
\mu \mathrm{m} / \mathrm{m} \\
\text { Two cross } \\
\text { frames }\end{array}$ & $\begin{array}{l}\text { Maximum } \\
\text { strain } \\
\mu \mathrm{m} / \mathrm{m} \\
\text { Three cross } \\
\text { frames }\end{array}$ & $\begin{array}{c}\text { Maximum } \\
\text { strain } \\
\mu \mathrm{m} / \mathrm{m} \\
\text { Five cross } \\
\text { frames }\end{array}$ \\
\hline Curved model & 288.9 & 296.6 & 327.2 \\
\hline $\begin{array}{c}\text { Straight } \\
\text { model }\end{array}$ & 172.2 & 174.1 & 170.3 \\
\hline $\begin{array}{l}\text { Percentage } \\
\text { difference }\end{array}$ & $40.4 \%$ & $41.3 \%$ & $48 \%$ \\
\hline
\end{tabular}

The spacing between cross frame affects the total deformation of the curved model clearly, where the deflection decrease with increasing of numbers of cross frame. As shown in tables (I TO IV) for the middle and exterior girders, the increase in the number of cross frame from two to three resulted in decrease the maximum deflection $(5.83 \%$ and $7.14 \%$ respectively), but slight decrease was noticed in the deformation

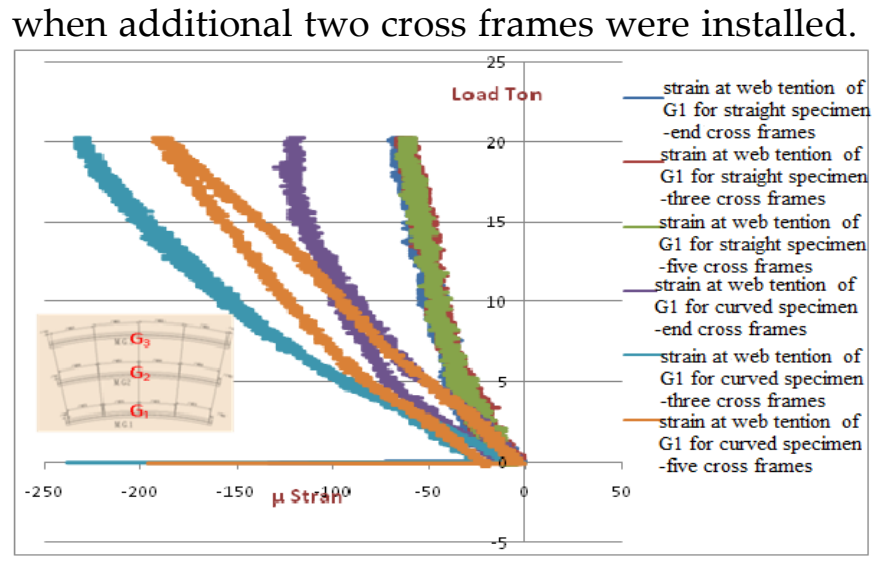

Fig. 16. Strain at tension zone of web of interior girder for straight and curved models with three cases of cross frame

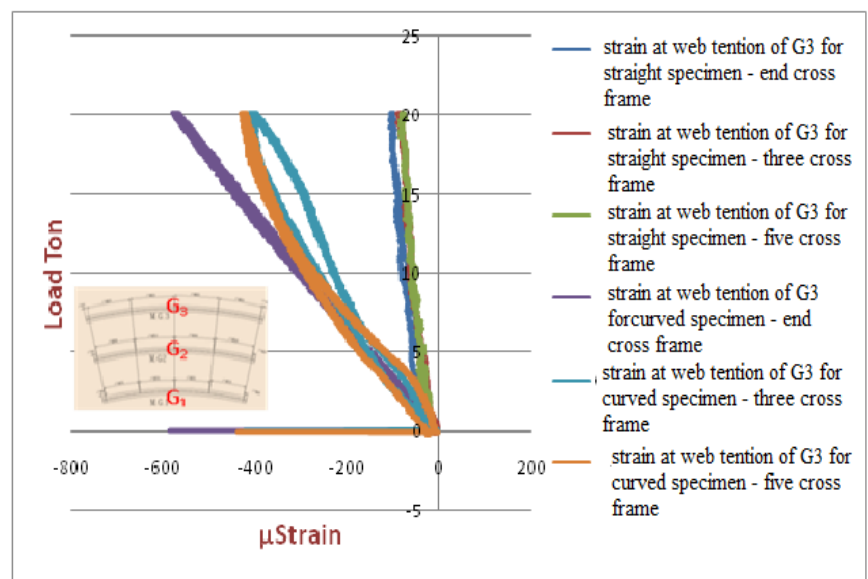

Fig. 17. Strain at web tension zone of exterior girder for straight and curved models with three cases of cross frames

TABLE VIII: MAXIMUM STRAIN AT TENSION ZONE OF WEB OF EXTERIOR GIRDER FOR STRAIGHT AND CURVED MODELS

\begin{tabular}{|c|c|c|c|}
\hline \multirow{3}{*}{ Cross frame } & Maximum & Maximum & Maximum \\
\hline & $\mu \mathrm{m} / \mathrm{m}$ & $\mu \mathrm{m} / \mathrm{m}$ & $\mu \mathrm{m} / \mathrm{m}$ \\
\hline & $\begin{array}{c}\text { Two cross } \\
\text { frames }\end{array}$ & $\begin{array}{l}\text { Three cross } \\
\text { frames }\end{array}$ & $\begin{array}{l}\text { Five cross } \\
\text { frames }\end{array}$ \\
\hline $\begin{array}{c}\text { Curved model } \\
\text { Strain } \mu \mathrm{m} / \mathrm{m}\end{array}$ & 568.39 & 396.1 & 415.29 \\
\hline $\begin{array}{l}\text { Straight model } \\
\text { Strain } \mu \mathrm{m} / \mathrm{m}\end{array}$ & 103.34 & 88.03 & 84.207 \\
\hline $\begin{array}{l}\text { Percentage } \\
\text { difference }\end{array}$ & $81.81 \%$ & $77.77 \%$ & $79.72 \%$ \\
\hline
\end{tabular}

The interior girder behaves differently, the deflection was increased with increasing the numbers of cross frames, this may be due to the transmission and redistribution of the applied load caused by the cross frames towards the shorter span girder.

In the straight composite model the effect of a number of cross frame more than three is negligible. This confirms the assumption that cross frame is as secondary member.

Tables (V to VIII) illustrate the effects of spacing between cross frames on the strain values for both 
curved and straight models. For both curved and straight models, the strain values behave normally (increasing with the load increasing). But the strain values of the curved model were higher when they compared with the straight model values. (The difference reaches $80 \%$ in the web and $48 \%$ in the bottom flange for exterior girder). Torsion moment in the curved model increases the stresses in the whole structure that may be due to the influence of curvature.

\section{CONCLUSIONS AND RECOMMENDATIONS}

- The straight model shows stiffer behavior than the curved model. Because it shows less deflection.

- The effect of Cross frame in straight model negligible for more than three cross frames.

- In the curved model, the use of the cross frame is essential.

- As the recommendation, for future experimental work the cross-section of the I-girders should be chosen to cater for the load distribution.

- An optimum spacing of the cross frame in real structure should be obtained from experimental of prototype of full scale of composite bridge.

\section{REFERENCES}

[1] Matthew, R. Tilley, Furman, w. barton and josé, pantaleongomez, "dynamic analysis and testing of a curved girder bridge," Virginia Transportation Research Council. Virginia Department of, (2006).

[2] Linzell D. Hall D. White D. (2004). Historical perspective on horizontally curved I-girder bridge design in United States. Journal of bridge engineering, ASCE. 9(3):218-29. Transportation and U.S. Federal Highway Administration 71624.

[3] Davidson J. S., Keller. M.A. and Yoo. C.H. (1996). Cross-frame spacing and parametric effects in horizontally curved I-girder bridges. ASCE Journal of Structural Engineering, 122(9): 1089-1096.

[4] Maneetes H. and Linzell D. (2003). Cross-frame and lateral bracing influence on curved steel bridge free vibration response. Journal of Constructional Steel Research. 59(9): 1101-1117.

[5] Mohammad Abedin and Armin B. Mehrabi," Effect of cross frames on load distribution of steel bridges with fractured girder", Department of Civil and Environmental Engineering., Florida International University., Miami, FL 33174, USA., 1 April 2020.

[6] Hall, Dann H. Grubb, Michael A. and Yoo, Chai H., "Improved design specifications for horizontally curved steel girder highway bridges," FINAL REPORT, National Cooperative
Highway Research Program Transportation Research Board, National Research Council, (1998).

[7] Doust. S, "Extending integral concepts to curved bridge systems", Civil Engineering Theses, dissertations and Student Research., Paper 41:10-22, 2011.

[8] Yoo C., Kang Y. and Davidson J. (1986). Buckling analysis of curved beams by finite element discretization. Journal of Engineering Mechanics. ASCE. 122(8):762-70.

[9] Schelling D., Namini A. and Fu C. (1989). Construction effects on bracing on curved I-girders. Journal of Structural Engineering. ASCE. 115(ST9):2145-65.

[10] AASHTO. AASHTO Guide Specifications for Horizontally Curved Steel Girder Highway Bridges., American Association of State Highway and Transportation Officials, Washington, D.C, (2003)

[11] Fageer, Badria A. M, Ahmed A. K. and Daoud Osama M. A. (Augast 2018). Comparative experimental study of behaviour of straight and horizontally curved composite bridges. $\mathrm{U}$ of $\mathrm{K}$ EJ. Vol.8 Issue 2 pp.7-14. 